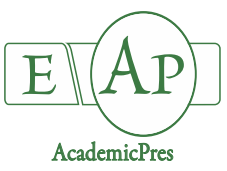

Chumroenphat T and Saensouk S (2021)

Notulae Botanicae Horti Agrobotanici Cluj-Napoca

Volume 49, Issue 3, Article number 12391

DOI: $10.15835 /$ nbha49312391

Research Article

\title{
Amino acids, bioactive compounds and biological activities of ten species from family Commelinaceae in Thailand
}

\section{Theeraphan CHUMROENPHAT ${ }^{1}$, Surapon SAENSOUK ${ }^{2 *}$}

\author{
${ }^{1}$ Mahasarakham University, Laboratory Equipment Center, Division of Research facilitation and dissemination, Kantarawichai \\ District, Maha Sarakham, 44150, Thailand; theeraphan.chum@hotmail.com \\ ${ }^{2}$ Mahasarakham University, Plant and Invertebrate Taxonomy and Its Applications Unit Group, Walai Rukhavej Botanical Research \\ Institute, Kantarawichai District, Maha Sarakham, 44150, Thailand; surapon.s@msu.ac.th (*corresponding author)
}

Commelinaceae is used for ethnobotany. However, bioactive compounds information of this family is few data. The aim here was to determine the bioactive compounds and quantify the antioxidant activity from leaves 10 species. Twenty amino acids were identified using LC/MS/MS. The antioxidant contents were evaluated by the total phenolic and total flavonoid content assays. The individual phenolic acids, flavonoids and vitamin $\mathrm{c}$ were identified by HPLC. The antioxidant activities detected were DPPH scavenging and FRAP assay. The total amino acids found in most samples studied ranging from 239 to $1012 \mu \mathrm{g} / \mathrm{g}$ DW. Vitamin C contents were in the range of 23 to $195 \mathrm{mg} / 100 \mathrm{~g} \mathrm{DW}$. Total phenolic and total flavonoid contents ranged from 11.3 to $35.7 \mathrm{mg} \mathrm{GAE} / \mathrm{g}$ DW and 56.7 to $368.7 \mathrm{mg} \mathrm{RE} / 100 \mathrm{~g} \mathrm{DW}$, respectively. All the species studied possessed strong antioxidant properties (DPPH and FRAP). This result can be applied for further development of functional foods or cosmetics.

Keywords: amino acids; antioxidants; Commelinaceae; flavonoids; phenolic acids

\section{Introduction}

Commelinaceae is an important tropical and subtropical plant found worldwide. There are approximately 37 genera with over 600 species discovered (Edeoga and Ogbebor, 1999). The dominant characteristic of the family is succulent stems and sheathing leaves (Wilson, 1981). Many species of this family are grown ornamental plants and for ethnobotany (González-Avila et al., 2003; Mensah et al., 2006; AlonsoCastro et al., 2011; Myriam et al., 2011). Thailand has one of the richest Commetlinaceae floras in the world. North-eastern Thailand provides a unique environment for the nurture of specific genotypes, being unusually dry and elevated. The biologically active compounds of many of these genotypes have never been reported. However, reports on the amino acids and vitamin $c$ have been slight with limited information of phytochemicals along with the biological activities of these plants.

In Thailand, the leaves of some Commelinaceae species are used in native dishes and some species are used in ancient folk medicine recipes. Numerous studies on their medicinal and nutritional properties have been conducted. The Commelinaceae species that are commonly consumed in Thailand include Murdannia loriformis (Hassk.) Rao \& Kamm., Tradescantia pallida (Rose) D.R.Hunt, Commelina bengalensis L. and $C$. clavate C.B.Clarke. They are used as vegetables in many traditional Thai foods. The leaves of $C$. diffusa had the

Received: 04 Jun 2021. Received in revised form: 05 Jul 2021. Accepted: 19 Jul 2021. Published online: 18 Aug 2021.

From Volume 49, Issue 1, 2021, Notulae Botanicae Horti Agrobotanici Cluj-Napoca journal uses article numbers in place of the traditional method of continuous pagination through the volume. The journal will continue to appear quarterly, as before, with four annual numbers. 
highest levels of alkaloids, ash, fat, and protein (Kamble, 2019). Currently, the development of functional foods from indigenous plants has been gaining great interest. For example, Murdannia loriformis (Hassk.) Rao \& Kamm has been processed to a dried powder as an instant herbal tea beverage as it has been reported to possess medicinal properties for anti-inflammatory, analgesic and antipyretic activities (Kunnaja et al., 2014). Although there are many published reports related to the bioactive compounds of the Commelinaceae family, there has been little information on individual phenolic acids or phytochemicals along with the biological activities of Commelinaceae in Thailand. In addition, the composition and content of these compounds could be affected by the growth conditions or growth locations (Ghasemzadeh et al., 2010; Butsat et al., 2009). The aim of this work is present for the first reported, the individual amino acids, phenolic acids, flavonoids and antioxidant activity found in 10 of the widest spread and used medicinal plants in north-eastern Thailand.

Therefore, we aimed to generate information about the amino acids, bioactive compounds and biological activities in 10 varieties of Commelinaceae grown in north-eastern Thailand, which is the biggest plain region in Thailand. The total phenolic contents, total flavonoid contents, along with antioxidant activities were determined, and individual phenolic and flavonoid acids of the studied species were quantified. This present study expects to provide beneficial data for wider use of these plants. This research project should offer a useful foundation for future studies on the development foods product for functional food in the future.

\section{Materials and Methods}

All the chemicals and standards for HPLC analysis, standards of phenolic acids ( $p$-hydroxybenzoic, gallic, caffeic, protocatechuic, sinapic, syringic, ferulic, $p$-coumaric, vanillic and chlorogenic acids), flavonoids (myricetin, rutin, apigenin, quercetin and kaempferol), amino acids (arginine, asparagine, alanine, aspartic acid, cysteine, glutamic acid, glutamine, glycine, leucine, isoleucine, histidine, methionine, lysine, proline, phenylalanine, serine, tryptophan, threonine, valine and tyrosine) and ascorbic acid were purchased from Sigma-Aldrich Co. (St. Louis, MO., U.S.A.). All other high-purity solvents for HPLC analysis were supplied from Merck (Darmstadt, Germany).

\section{Plant material and sample preparation}

Whole plants of 10 edible species from Commelinaceae were collected from the north-eastern region of Thailand in 2020. Advice from local people was used as the basis for characterizing samples according to their uses, especially for being edible. They were identified by Dr. Surapon Saensouk, specialist plant taxonomist, where the specimens were positioned in the herbarium. The characteristics of the plants are given in Table 1. The leaves of selected species were thoroughly washed in tap water, freeze-dried and crushed into a powder using a dry grinder. The ground samples were kept at $-20^{\circ} \mathrm{C}$ until further analysis.

\section{Amino acids by $L C / M S / M S$}

Samples were analysed for amino acids using a method as previously reported by Chumroenphat et al. (2021). The LC/MS/MS was performed using a LCMS-8030 triple-quadrupole mass spectrometer (Shimadzu, Kyoto, Japan) operated in the ESI mode and a Shimadzu LC-20AC series HPLC system (Shimadzu, Kyoto, Japan). The 20 of individual amino acids was identified by their $\mathrm{m} / \mathrm{z}$ values and by comparison with the retention time of external standards.

Sample extraction of phenolic contents and antioxidant activity

The extraction of phenolic contents and antioxidant activity were performed according to Chumroenphat et al. (2019). 
Table 1. The characteristics of the selected plants

\begin{tabular}{|c|c|c|c|c|}
\hline Sample name & Local name & $\begin{array}{l}\text { Collector } \\
\text { number }\end{array}$ & Part of use & Reference \\
\hline C. axillaris (L.) D.Don. ex Sweet & Phak-plap-na & TC-2021-001 & $\begin{array}{c}\text { Leaves: } \\
\text { vegetable; } \\
\text { herbal medicine }\end{array}$ & $\begin{array}{c}\text { Regis and } \\
\text { Gabriel, } 2017\end{array}$ \\
\hline C. bengalensis $\mathrm{L}$ & Phak-plap-bai-kwang & TC-2021-002 & $\begin{array}{l}\text { leaves: vegetable } \\
\text { herbal medicine }\end{array}$ & $\begin{array}{c}\text { Kokilavani et } \\
\text { al., } 2014\end{array}$ \\
\hline C. diffusa Burm.f. & Phak-plap-bai-cab & TC-2021-003 & leaves: vegetable & Kamble, 2019 \\
\hline C. clavata C.B.Clarke & Phak-plap-bai-sak & TC-2021-004 & leaves: vegetable & - \\
\hline C. fragrans (Lindl.) Woodson & Vassana-lueang & TC-2021-005 & leaves: vegetable & - \\
\hline C. repens (Jacq.) L. & Yha-pai-nam-lek & TC-2021-006 & leaves: vegetable & - \\
\hline $\begin{array}{l}\text { M. loriformis (Hassk.) Rao \& } \\
\text { Kamm. }\end{array}$ & Yha-pak-king & TC-2021-007 & $\begin{array}{c}\text { leaves: food; } \\
\text { vegetable; } \\
\text { herbal medicine }\end{array}$ & $\begin{array}{c}\text { Cheeptham } \\
\text { and Towers, } \\
2002\end{array}$ \\
\hline T. fluminensis Vell & Yha-pai-nam & TC-2021-008 & $\begin{array}{c}\text { leaves: herbal } \\
\text { medicine }\end{array}$ & $\begin{array}{c}\text { Tan and Kwan, } \\
2020 \\
\end{array}$ \\
\hline T. pallida (Rose) D.R.Hunt. & Hua-chai-sri-muang & TC-2021-009 & $\begin{array}{c}\text { leaves: herbal } \\
\text { medicine }\end{array}$ & $\begin{array}{c}\text { Tan and Kwan, } \\
2020\end{array}$ \\
\hline T. spathacea Swartz. & Wan-kab-hoi-chiaw & TC-2021-010 & $\begin{array}{c}\text { leaves: herbal } \\
\text { medicine }\end{array}$ & $\begin{array}{c}\text { Tan and Kwan, } \\
2020\end{array}$ \\
\hline
\end{tabular}

\section{Total phenolic contents (TPC)}

The TPC test was done following the Folin-Ciocalteau method used in a previous study (Al-Duais et al., 2009) with some modified. Folin-Ciocalteu reagent was prepared $10 \%$ in distilled water and then $100 \mu$ lof that reagent was mixed with $20 \mu \mathrm{l}$ of each extract were pipetted to the corresponding well of the 96-well plate. The mixture was incubated in incubator for $4 \mathrm{~min}$ and $75 \mu \mathrm{l}$ of $10 \%$ sodium carbonate solution added. Then the mixture was left to stand at room temperature for $2 \mathrm{~h}$. The solution absorbance was measured at $725 \mathrm{~nm}$ using a Varioskan Lux Multimode microplate reader (Thermo Fisher Scientific, USA). The results were expressed in mg gallic acid equivalents (mg GAE/g DW).

\section{Total flavonoid contents (TFC)}

Total flavonoid contents were determined using the colorimetric method described by Zhishen et al. (1999) with some modified. In brief, $25 \mu \mathrm{L}$ of extract was mixed with $100 \mu \mathrm{L}$ of purified water in the 96-well plate followed by the addition of $10 \mu \mathrm{L}$ of a $5 \% \mathrm{NaNO}_{2}$ solution. After shanking for $5 \mathrm{~min}, 15 \mu \mathrm{L}$ of a $10 \%$ $\mathrm{AlCl}_{3} 6 \mathrm{H}_{2} \mathrm{O}$ solution was added to the mixture with shaker for 6 min prior to the addition of $50 \mu \mathrm{L}$ of $1 \mathrm{M}$ $\mathrm{NaOH}$ and $50 \mu \mathrm{L}$ of purified water. The mixture measured instantly at $510 \mathrm{~nm}$ by using a Varioskan Lux Multimode microplate reader (Thermo Fisher Scientific, USA). The results were expressed as mg rutin equivalents per 100-gram sample (mg RE/100 g DW).

\section{Phenolic acids and flavonoids by HPLC}

The individuals of phenolic acids and flavonoids were extracted and identified by HPLC according to Kaisoon et al. (2012). The phenolic acids and flavonoids in the extracts were identified by comparing their relative retention times with external standards.

\section{Vitamin C by HPLC}

The extraction of vitamin C was performed according to Siriamornpun and Kaewseejan (2017), A Shimadzu LC-20AC series HPLC system with diode array detector (Shimadzu, Tokyo, Japan) was used for analyses. 


\section{Antioxidant activities}

\section{DPPH free radical scavenging assay}

The scavenging DPPH radials of the extracts were studied using a previously published method with some modifications (Rivero-Pérez et al., 2007). The extract or control $(20 \mu \mathrm{L})$ of was added to $180 \mu \mathrm{L}$ of 60 $\mu \mathrm{M}$ DPPH solution dissolved in methanol. The mixture was shaken vigorously and left to stand at an ambient temperature for $30 \mathrm{~min}$ in the dark. and then the absorbance was detected at $517 \mathrm{~nm}$ using a microplate reader (Varioskan Lux, Thermo Fisher Scientific, USA). Results were expressed as mg Trolox equivalents (TE) per one gram of dried sample (mg TE/g DW).

Ferric reducing/antioxidant power assay (FRAP)

The procedures used for this assay were according to the method measured based on an FRAP assay described from Li et al. (2017) with some modifications. An aliquot of $180 \mu \mathrm{L}$ of FRAP reagent was briefly mixed with $5 \mu \mathrm{L}$ of extract in the 96-well plate. FRAP reagent was freshly prepared by mixing $0.3 \mathrm{M}$ acetate buffer (pH 3.6), $10 \mathrm{mM} \mathrm{TPTZ} \mathrm{in} 40 \mathrm{mM} \mathrm{HCl}$ and $20 \mathrm{mM} \mathrm{FeCl}_{3} 6 \mathrm{H}_{2} \mathrm{O}$ in a 10:1:1 ratio at $37^{\circ} \mathrm{C}$. The mixture was shaken and incubated for $4 \mathrm{~min}$ at $37^{\circ} \mathrm{C}$. The absorbance was read at $593 \mathrm{~nm}$ using a microplate reader (Varioskan Lux, Thermo Fisher Scientific, USA). Results were expressed as mg $\mathrm{FeSO}_{4}$ per one gram of dried sample ( $\mathrm{mg} \mathrm{FeSO}_{4} / \mathrm{g}$ DW).

\section{Statistical analysis}

All data were analysed using a statistical program. These reported to be as the mean \pm one standard deviation (SD) of three replicates and data were analysed using a one-way analysis of variance (ANOVA). The significance relative to the control.

\section{Results and Discussion}

The investigation of amino acids present in different kinds of plants has been a subject of interest in different studies. This work identifies both the qualification and quantitation using LC/MS/MS of 20 amino acids including nine essential amino acids in Commelinaceae for the first time, so providing useful information for further use of this plant. The results showed that the amino acids were found in all samples studied. On the other hand, cysteine and glycine were absent from all samples (Table 2). The highest total amino acids found

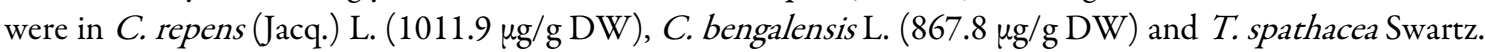
$(762.0 \mu \mathrm{g} / \mathrm{g} \mathrm{DW})$, respectively. Glutamic acid and phenylalanine were found to have the highest content (137 $\mu \mathrm{g} / \mathrm{g}$ DW). The total levels of amino acids found in Commelinaceae were considered to be lower than for other plants previously reported, such as in bean, potato, rice and mushroom (Ribeiro et al., 2008; Khalid et al., 2016; Huang et al., 2019; Ratseewo et al., 2020). However, this is an important nutrient for the human body.

The results from our present study have demonstrated that the amino acid content and composition varied greatly among varieties; however, free amino acid variability may also be related to different environmental conditions, using the discriminant and cluster analysis method. Therefore, further studies on this aspect are needed. 
Chumroenphat T and Saensouk S (2021). Not Bot Horti Agrobo 49(3):12391

Table 2. Contents of amino acid in selected species from Commelinaceae analysed by LC/MS/MS

\begin{tabular}{|c|c|c|c|c|c|c|c|c|c|c|}
\hline \multirow{2}{*}{$\begin{array}{l}\text { Amino acid content } \\
(\mu \mathrm{g} / \mathrm{g} D W)\end{array}$} & \multicolumn{10}{|c|}{ Sample name } \\
\hline & CA & $\mathrm{CB}$ & $\mathrm{CC}$ & $\mathrm{CD}$ & $\mathrm{CF}$ & $\mathrm{CR}$ & ML & $\mathrm{TF}$ & $\mathrm{TP}$ & TS \\
\hline Alanine & $17.43 \pm 1.25 \mathrm{i}$ & $19.18 \pm 0.52 \mathrm{i}$ & $6.70 \pm 0.26 j$ & $21.80 \pm 1.77 \mathrm{i}$ & $3.40 \pm 0.31 \mathrm{~h}$ & $17.05 \pm 2.33 \mathrm{k}$ & $12.18 \pm 1.24 \mathrm{k}$ & $8.38 \pm 1.35 \mathrm{k}$ & $36.39 \pm 2.99 \mathrm{f}$ & $53.16 \pm 3.33 \mathrm{e}$ \\
\hline Arginine & $46.05 \pm 0.39 \mathrm{c}$ & $74.44 \pm 0.78 \mathrm{c}$ & $54.99 \pm 0.15 \mathrm{a}$ & $62.87 \pm 0.55 \mathrm{~b}$ & $66.61 \pm 0.33$ a & $52.03 \pm 0.70 \mathrm{f}$ & $65.72 \pm 0.47 \mathrm{~d}$ & $52.12 \pm 0.78 \mathrm{~b}$ & $51.33 \pm 0.18 \mathrm{~d}$ & $67.89 \pm 0.55 \mathrm{c}$ \\
\hline Asparagine & $5.94 \pm 0.88 \mathrm{~m}$ & $17.21 \pm 0.20 \mathrm{ij}$ & $5.03 \pm 1.08 \mathrm{jk}$ & $21.30 \pm 0.94 \mathrm{i}$ & $2.40 \pm 0.02 \mathrm{i}$ & $10.93 \pm 2.631$ & $7.65 \pm 0.26 \mathrm{~m}$ & $93.06 \pm 4.25 \mathrm{a}$ & $100.40 \pm 2.06 \mathrm{a}$ & $20.25 \pm 4.31 \mathrm{j}$ \\
\hline Cysteine & ND & ND & ND & ND & ND & ND & ND & $\mathrm{ND}$ & ND & $\mathrm{ND}$ \\
\hline Glutamine & $28.68 \pm 1.38 \mathrm{~g}$ & $21.41 \pm 0.94 \mathrm{~h}$ & $8.36 \pm 0.19 \mathrm{~h}$ & $30.46 \pm 2.52 \mathrm{gh}$ & $7.15 \pm 0.35 \mathrm{f}$ & $27.80 \pm 1.81 \mathrm{i}$ & $25.49 \pm 3.23 \mathrm{~h}$ & $7.07 \pm 0.71 \mathrm{k}$ & $41.83 \pm 1.83 \mathrm{e}$ & $31.15 \pm 1.96 \mathrm{i}$ \\
\hline Glutamic acid & $41.34 \pm 1.99 \mathrm{~d}$ & $137.64 \pm 10.08 \mathrm{a}$ & $53.87 \pm 0.86 \mathrm{~h}$ & $34.41 \pm 2.11 \mathrm{~g}$ & $10.35 \pm 0.92 \mathrm{e}$ & $96.22 \pm 5.38 \mathrm{~d}$ & $110.18 \pm 8.71 \mathrm{a}$ & $29.41 \pm 1.18 \mathrm{f}$ & $61.42 \pm 4.54 \mathrm{c}$ & $86.87 \pm 3.58 \mathrm{~b}$ \\
\hline Glycine & ND & ND & ND & ND & ND & ND & ND & $\mathrm{ND}$ & ND & $\mathrm{ND}$ \\
\hline Histidine & $26.80 \pm 1.52 \mathrm{~g}$ & $9.33 \pm 0.331$ & $7.87 \pm 0.34 \mathrm{i}$ & $11.87 \pm 0.72 \mathrm{k}$ & $14.53 \pm 0.81 \mathrm{~cd}$ & $32.05 \pm 2.53 \mathrm{~h}$ & $6.83 \pm 0.26 \mathrm{n}$ & $14.06 \pm 0.22 \mathrm{j}$ & $23.55 \pm 1.87 \mathrm{~h}$ & $4.31 \pm 0.72 \mathrm{~m}$ \\
\hline Isoleucine & $29.49 \pm 1.80 \mathrm{f} \mathrm{g}$ & $50.65 \pm 0.94 \mathrm{f}$ & $9.21 \pm 0.81 \mathrm{~g}$ & $40.17 \pm 0.56 \mathrm{e}$ & $3.42 \pm 0.80 \mathrm{~h}$ & $70.33 \pm 0.84 \mathrm{e}$ & $33.35 \pm 2.23 \mathrm{~g}$ & $17.22 \pm 0.63 \mathrm{i}$ & $17.32 \pm 0.81 \mathrm{i}$ & $40.67 \pm 0.87 \mathrm{~g}$ \\
\hline Leucine & $30.06 \pm 1.65 \mathrm{f}$ & $52.31 \pm 2.70 \mathrm{f}$ & $13.29 \pm 0.83 \mathrm{e}$ & $40.27 \pm 0.29 \mathrm{e}$ & $7.44 \pm 0.60 \mathrm{f}$ & $68.47 \pm 0.99 \mathrm{e}$ & $34.65 \pm 2.08 \mathrm{~g}$ & $19.65 \pm 0.32 \mathrm{~h}$ & $21.74 \pm 1.82 \mathrm{~h}$ & $36.41 \pm 1.22 \mathrm{~h}$ \\
\hline Lysine & $23.32 \pm 0.34 \mathrm{~h}$ & $23.23 \pm 1.71 \mathrm{~h}$ & $5.94 \pm 1.42 \mathrm{jk}$ & $32.15 \pm 2.28 \mathrm{~g}$ & $7.48 \pm 0.56 \mathrm{f}$ & $29.54 \pm 0.98 \mathrm{~h}$ & $20.78 \pm 1.44 j$ & $8.65 \pm 0.58 \mathrm{k}$ & $42.97 \pm 2.12 \mathrm{e}$ & $32.94 \pm 1.46 \mathrm{i}$ \\
\hline Methionine & $30.59 \pm 0.81 \mathrm{f}$ & $73.81 \pm 3.98 \mathrm{c}$ & $29.20 \pm 0.78 \mathrm{~d}$ & $45.39 \pm 3.14 \mathrm{~d}$ & $13.30 \pm 0.51 \mathrm{~d}$ & $105.70 \pm 3.86 \mathrm{c}$ & $28.88 \pm 0.56 \mathrm{~h}$ & $25.14 \pm 1.17 \mathrm{~g}$ & $62.11 \pm 5.13 \mathrm{c}$ & $59.97 \pm 1.44 \mathrm{~d}$ \\
\hline Phenylalanine & $59.43 \pm 1.31 \mathrm{a}$ & $101.65 \pm 1.92 \mathrm{~b}$ & $47.51 \pm 1.49 \mathrm{c}$ & $87.72 \pm 1.07 \mathrm{a}$ & $15.71 \pm 0.35 \mathrm{c}$ & $137.32 \pm 0.71 \mathrm{a}$ & $53.56 \pm 0.74 \mathrm{f}$ & $46.07 \pm 1.34 \mathrm{~d}$ & $53.99 \pm 2.73 \mathrm{~d}$ & $10.67 \pm 0.591$ \\
\hline Proline & $9.43 \pm 0.611$ & $18.47 \pm 1.88 \mathrm{i}$ & $6.76 \pm 0.60 \mathrm{j}$ & $10.73 \pm 0.831$ & $6.79 \pm 0.19 \mathrm{~g}$ & $24.25 \pm 2.88 \mathrm{j}$ & $7.77 \pm 0.47 \mathrm{~m}$ & $3.96 \pm 0.43 \mathrm{~m}$ & $12.76 \pm 0.37 \mathrm{j}$ & $13.64 \pm 1.04 \mathrm{k}$ \\
\hline Serine & $15.46 \pm 4.01 \mathrm{j}$ & $13.83 \pm 0.66 \mathrm{k}$ & $7.19 \pm 0.14 \mathrm{i}$ & $12.27 \pm 1.22 \mathrm{k}$ & $13.31 \pm 0.24 \mathrm{~d}$ & $11.27 \pm 2.801$ & $9.53 \pm 1.061$ & $9.52 \pm 0.78 \mathrm{k}$ & $12.59 \pm 0.54 \mathrm{j}$ & $18.45 \pm 1.56 \mathrm{j}$ \\
\hline Threonine & $12.82 \pm 1.40 \mathrm{k}$ & $17.13 \pm 0.16 \mathrm{ij}$ & $7.13 \pm 1.14 \mathrm{ij}$ & $16.46 \pm 1.87 \mathrm{j}$ & $3.41 \pm 0.03 \mathrm{~h}$ & $12.66 \pm 1.011$ & $9.55 \pm 0.741$ & $5.42 \pm 0.251$ & $11.47 \pm 0.77 \mathrm{j}$ & $14.36 \pm 1.14 \mathrm{k}$ \\
\hline Tryptophan & $35.79 \pm 0.84 \mathrm{e}$ & $57.16 \pm 1.38 \mathrm{e}$ & $30.00 \pm 0.17 \mathrm{~d}$ & $56.73 \pm 0.67 \mathrm{c}$ & $16.82 \pm 0.67 \mathrm{c}$ & $109.41 \pm 1.08 \mathrm{~b}$ & $56.98 \pm 0.51 \mathrm{e}$ & $50.84 \pm 0.58 \mathrm{c}$ & $64.07 \pm 1.70 \mathrm{c}$ & $105.82 \pm 1.37$ a \\
\hline Tyrosine & $34.90 \pm 1.17 \mathrm{e}$ & $60.21 \pm 2.73 \mathrm{~d}$ & $22.72 \pm 0.64 \mathrm{e}$ & $29.37 \pm 1.45 \mathrm{~h}$ & $35.81 \pm 0.75 \mathrm{~b}$ & $103.38 \pm 5.00 \mathrm{c}$ & $88.36 \pm 5.26 \mathrm{~b}$ & $16.25 \pm 0.85 \mathrm{i}$ & $68.61 \pm 1.71 \mathrm{~b}$ & $82.95 \pm 1.65 \mathrm{~b}$ \\
\hline Total & $553.78 \pm 4.57$ & $867.87 \pm 2.20$ & $342.99 \pm 0.84$ & $650.12 \pm 1.57$ & $239.01 \pm 0.48$ & $1011.97 \pm 2.25$ & $674.09 \pm 2.05$ & $457.49 \pm 0.98$ & $753.10 \pm 1.99$ & $762.05 \pm 1.77$ \\
\hline
\end{tabular}

Values are expressed as mean \pm SD of triplicate measurements $(\mathrm{n}=3)$. Means with different letters are significantly different at $p<0.05$ within the same column. CA: $C$. axillaris $(\mathrm{L}$.) D.Don. ex Sweet; CB: C. bengalensis L.; CC: C. clavata C.B. Clarke; CD: C. diffusa Burm f; CF: C. fragrans (Lindl.) Woodson; CR: C. repens (Jacq.) L; ML: M. loriformis (Hassk.) Rao \& Kamm.; TF: T. fluminensis Vell.; TP: T. pallida (Rose) D.R.Hunt.; TS: T. spathacea Swartz. 
TPC and TFC are indicative of the levels of bioactive compounds that are beneficial to humans when found in high levels. The phenolic compounds have raised interest from the scientific community in recent times. In this study, the total phenolic contents were estimated in 10 selected species from Commelinaceae. The results are shown in Figure 1 (a). The levels of TPC in the evaluated Commelinaceae varied significantly, from 11.3 to $35.7 \mathrm{mg}$ GAE/gDW. The highest values of TPC were found in C. clavata C.B. Clarke (35.7 mgGAE/g DW) and T. spathacea Swartz. (34.0 mgGAE/g DW), followed by C. fragrans (Lindl.) Woodson and C.axillaris (L.) D. Don. ex Sweet., while M. loriformis (Hassk.) Rao \& Kamm. contained the lowest TPC compared to the other plants studied. In this study, the content of TPC was higher than those described in other species of Commelinaceae family (Tan et al., 2014).

Flavonoids are a diverse group of phenolic compounds distributed in higher plants, and they have been documented to have great antioxidant potential. As presented in Figure1(b), there were significant variations in the TFC in the selected species, which ranged from 56.7 to $368.7 \mathrm{mg}$ RE/100 $\mathrm{g} \mathrm{DW}$. The highest TFC was found in T. fluminensis ( $368.7 \mathrm{mg} \mathrm{RE} / 100 \mathrm{~g} \mathrm{DW}$ ), followed by T. spathaceaSwartz. (134.7mg RE/100 g DW) and C. clavata (L.) D.Don. ex Sweet (55.89 mg RE/100 g DW). The lowest TFC levels appeared to have no statistical significance detected in M. loriformis (Hassk.) Rao \& Kamm., C. diffusa Burm.f, T. pallida (Rose) D.R.Hunt and C. repens (Jacq.) L. The results section of this study suggested that flavonoids are not predominant in these selected species. Additionally, T. spathacea Swartz. and C. clavata C.B.Clarke were the richest source of phenolic compound and flavonoids.

Vitamin $\mathrm{c}$ is a good antioxidant, and many Commelinaceae species have been reported to contain vitamin c. Vitamin c contents in selected species from Commelinaceae are displayed in Figure 1(c). The amount of vitamin C ranged from $23.5 \mathrm{mg} / 100 \mathrm{~g} \mathrm{DW}$ in C. fragransto (Lindl.) Woodson $195.4 \mathrm{mg} / 100 \mathrm{~g} \mathrm{DW}$ in $T$. pallida (Rose) D.R.Hunt . Vitamin c is abundant in fruits (Kubola et al., 2011). Commelinaceae species can also be an alternative source of vitamin $c$, as indicated by this study. The findings obtained in this study conform to a previous study that presented a vitamin C content of $44.8 \mathrm{mg} / 100 \mathrm{~g} \mathrm{DW}$ in $C$. diffusa Burm. f. (Kamble, 2019). Despite the fact that fruits are high in vitamin C. According to this study, Commelinaceae species can also be used as a source of vitamin C.

The Commelinaceae extracts were identified and quantified using HPLC. The distribution of phenolic acids and flavonoid compounds are presented in Table 3. The levels of total phenolic acid in the evaluated Commelinaceae varied significantly, from 189.9 to $2704.1 \mu \mathrm{g} / \mathrm{g}$ DW. The highest values of total phenolic acid were found in C. clavata C.B.Clarke $(2704.1 \mu \mathrm{g} / \mathrm{g} \mathrm{DW})$, while T. spathacea Swartz. (189.9 $\mu \mathrm{g} / \mathrm{g} \mathrm{DW})$ contained the lowest total phenolic acid compared to the other plants studied. Among all samples of Commelinaceae, $p$-hydroxybenzoic acid and sinapic acid were identified as the predominant phenolic acid found in C. clavata C.B.Clarke (2063.2 $\mu \mathrm{g} / \mathrm{g} \mathrm{DW}$ ) and C. fragrans (Lindl.) Woodson (2039.3 $\mu \mathrm{g} / \mathrm{g} \mathrm{DW).} \mathrm{The}$ minor phenolic acids, vanillic acid and chlorogenic acid, were detected in the Commelinaceae extracts. The five flavonoids (quercetin, kaempferol, rutin, apigenin and myricetin) were detected by HPLC. The quantifications of the five flavonoids based on calibration curves of authentic standards are presented in Table 4. Flavonoids were detected in all samples with significant differences among the samples $(p<0.05)$. Rutin was a major flavonoid in C. clavata C.B.Clarke $(11460.44 \mu \mathrm{g} / 100 \mathrm{~g}$ DW). Chorismate, the final product of the Shikimate pathway, is a precursor of the aromatic amino acid L-phenylalanine, from which benzoic and cinnamic acid derivatives have their biosynthetic origin. These phenolic acids are naturally found in plants and classified by constitutive carbon structures. They are derived and biosynthetic in origin from the aromatic amino acid Lphenylalanine, which is synthesized from chorismate, the final product in the shikimate pathway. 

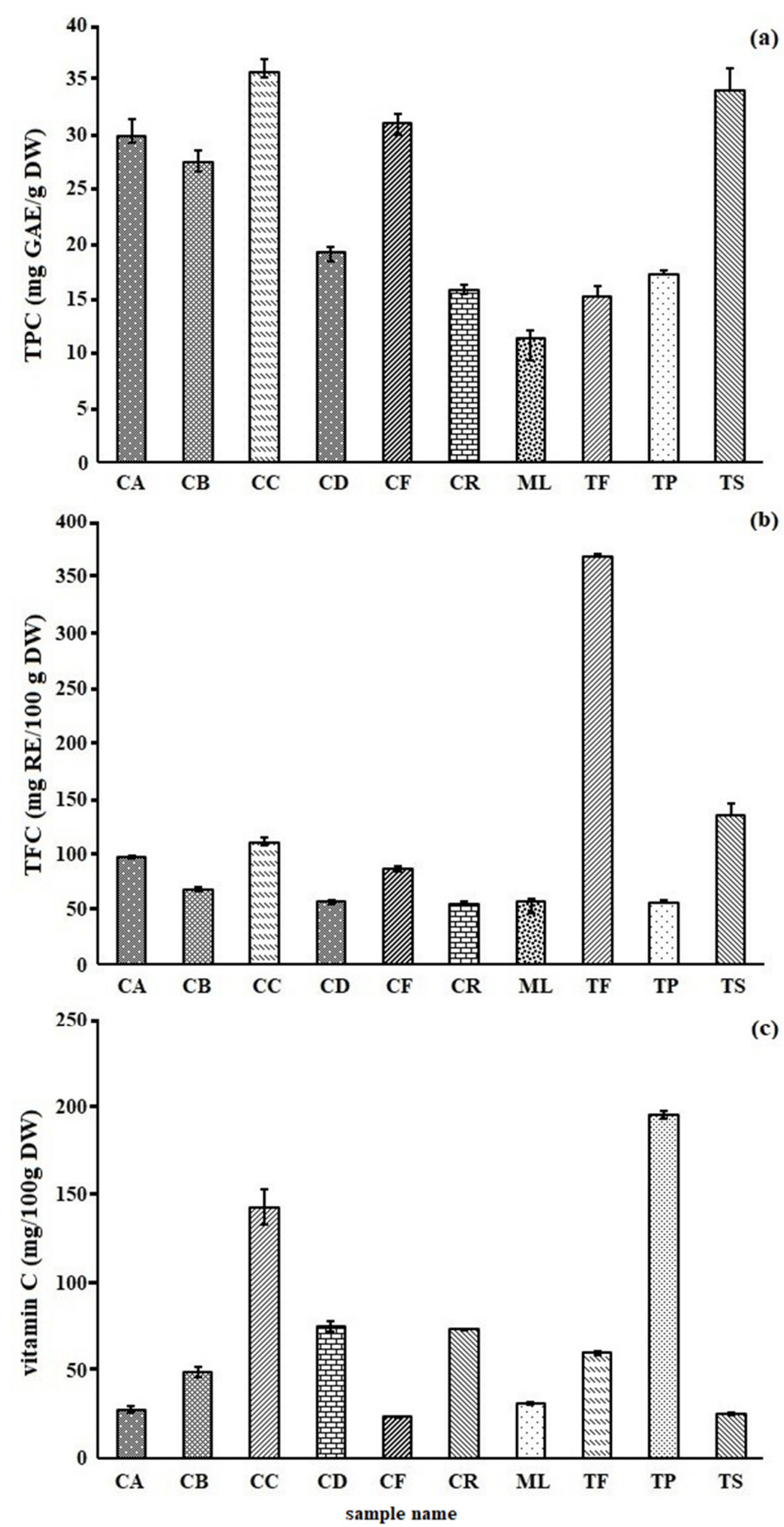

Figure 1. Contents of total phenolics, total flavonoids and vitamin c in Commelinaceae plants.; (a): total phenolic content; (b): total flavonoid content; (c): vitamin c content; CA: C. axillaris (L.) D.Don. ex Sweet; CB: C. bengalensis L.; CC: C. clavata C.B.Clarke; CD: C. diffusa Burm f; CF: C. fragrans (Lindl.) Woodson; CR: C. repens (Jacq.) L; ML: M. loriformis (Hassk.) Rao \& Kamm.; TF: T. fluminensis Vell.; TP: T. pallida(Rose) D.R.Hunt.; TS: T. spathacea Swartz. 
Table 3. Contents of phenolic acids in selected species from Commelinaceae

\begin{tabular}{|c|c|c|c|c|c|c|c|c|c|c|c|}
\hline \multirow{2}{*}{$\begin{array}{l}\text { Sample } \\
\text { name }\end{array}$} & \multicolumn{10}{|c|}{ Phenolic acid contents $(\mu \mathrm{g} / \mathrm{g}, \mathrm{DW})$} & \multirow{2}{*}{$\begin{array}{c}\text { Total phenolic } \\
\text { acid }(\mu \mathrm{g} / \mathrm{g}, \mathrm{DW})\end{array}$} \\
\hline & GA & PCA & $p$-OH & ChA & $\mathrm{VA}$ & $\mathrm{CA}$ & SyA & $p$-CA & $\mathrm{FA}$ & SA & \\
\hline $\mathrm{CA}$ & $62.86 \pm 1.62 \mathrm{e}$ & $\mathrm{ND}$ & $417.53 \pm 26.78 c$ & ND & ND & $62.96 \pm 0.68 \mathrm{~b}$ & $17.30 \pm 0.15 b$ & $12.81 \pm 0.97 \mathrm{e}$ & $\mathrm{ND}$ & $910.86 \pm 8.80 \mathrm{c}$ & $1484.32 \pm 3.90 \mathrm{c}$ \\
\hline CB & $23.81 \pm 0.64 \mathrm{~h}$ & $11.37 \pm 0.21 \mathrm{c}$ & $4.60 \pm 1.18 \mathrm{~g}$ & $\mathrm{ND}$ & ND & $146.65 \pm 3.32 \mathrm{a}$ & $24.06 \pm 1.93 \mathrm{a}$ & $183.48 \pm 4.56 \mathrm{~b}$ & ND & $1307.15 \pm 16.84 \mathrm{~b}$ & $1744.12 \pm 2.87 \mathrm{~b}$ \\
\hline $\mathrm{CC}$ & $34.82 \pm 0.56 \mathrm{~g}$ & $1.49 \pm 0.29 \mathrm{f}$ & $2063.28 \pm 30.04 \mathrm{a}$ & ND & ND & $3.15 \pm 0.10 \mathrm{~d}$ & ND & $9.56 \pm 0.86 \mathrm{f}$ & $442.18 \pm 5.98 \mathrm{~b}$ & $149.67 \pm 2.32 \mathrm{f}$ & $2704.15 \pm 1.44 \mathrm{a}$ \\
\hline CD & $45.33 \pm 0.42 \mathrm{f}$ & $1.95 \pm 0.35 \mathrm{ef}$ & $46.65 \pm 0.53 \mathrm{~g}$ & $13.15 \pm 0.09 \mathrm{a}$ & $\mathrm{ND}$ & $2.64 \pm 0.09 \mathrm{e}$ & $16.59 \pm 0.03 \mathrm{~b}$ & $2.86 \pm 0.05 \mathrm{~g}$ & $243.18 \pm 1.72 \mathrm{c}$ & $160.65 \pm 4.69 \mathrm{e}$ & $533.00 \pm 0.80 \mathrm{~g}$ \\
\hline $\mathrm{CF}$ & $35.75 \pm 0.90 \mathrm{~g}$ & $96.88 \pm 0.27 \mathrm{a}$ & $94.45 \pm 0.92 \mathrm{~d}$ & $0.63 \pm 0.33 \mathrm{~d}$ & $\mathrm{ND}$ & $\mathrm{ND}$ & $8.66 \pm 9.38 \mathrm{c}$ & $201.86 \pm 2.90 \mathrm{a}$ & $148.96 \pm 3.94 \mathrm{~d}$ & $2039.35 \pm 17.64 \mathrm{a}$ & $791.13 \pm 3.63 \mathrm{f}$ \\
\hline CR & $166.09 \pm 0.70 \mathrm{a}$ & $8.34 \pm 1.28 \mathrm{~d}$ & $61.82 \pm 0.70 \mathrm{e}$ & $0.63 \pm 0.36 \mathrm{~d}$ & ND & $26.55 \pm 0.21 \mathrm{c}$ & $23.57 \pm 2.14 \mathrm{a}$ & $83.60 \pm 2.49 \mathrm{~d}$ & $664.31 \pm 10.74 \mathrm{a}$ & $114.76 \pm 1.46 \mathrm{~h}$ & $1149.67 \pm 2.01 \mathrm{e}$ \\
\hline ML & $75.01 \pm 3.00 \mathrm{~d}$ & $\mathrm{ND}$ & $50.02 \pm 4.26 \mathrm{f}$ & $0.73 \pm 0.13 \mathrm{~d}$ & $\mathrm{ND}$ & $\mathrm{ND}$ & $8.64 \pm 2.57 \mathrm{c}$ & $89.33 \pm 1.00 \mathrm{c}$ & $94.89 \pm 5.22 \mathrm{~d}$ & $135.93 \pm 6.49 \mathrm{~g}$ & $454.55 \pm 2.27 \mathrm{~h}$ \\
\hline TF & $102.40 \pm 0.57 \mathrm{c}$ & $8.82 \pm 1.37 \mathrm{~d}$ & $672.13 \pm 1.67 \mathrm{~b}$ & $2.45 \pm 0.18 \mathrm{~b}$ & $0.86 \pm 0.28 \mathrm{~b}$ & $\mathrm{ND}$ & $\mathrm{ND}$ & $9.49 \pm 0.93 \mathrm{f}$ & $421.27 \pm 3.92 \mathrm{~b}$ & $226.44 \pm 1.12 \mathrm{~d}$ & $1443.86 \pm 1.00 \mathrm{~d}$ \\
\hline TP & $152.55 \pm 2.06 \mathrm{~b}$ & $2.63 \pm 0.82 \mathrm{e}$ & $39.52 \pm 0.29 \mathrm{~h}$ & $\mathrm{ND}$ & $\mathrm{ND}$ & ND & ND & $1.58 \pm 0.03 \mathrm{~g}$ & $12.07 \pm 1.03 \mathrm{e}$ & $18.68 \pm 1.87 \mathrm{j}$ & $227.03 \pm 0.61 \mathrm{j}$ \\
\hline TS & $16.82 \pm 1.87 \mathrm{i}$ & $25.74 \pm 1.67 \mathrm{~b}$ & $39.99 \pm 0.41 \mathrm{~h}$ & $1.00 \pm 0.14 \mathrm{c}$ & $5.07 \pm 0.15 \mathrm{a}$ & ND & ND & $10.56 \pm 0.40 \mathrm{f}$ & ND & $90.81 \pm 0.46 \mathrm{i}$ & $189.99 \pm 3.47 \mathrm{i}$ \\
\hline
\end{tabular}

Values are expressed as mean \pm SD of triplicate measurements $(n=3)$. Means with different letters are significantly different at $\mathrm{p}<0.05$ within the same column.

CA: C. axillaris (L.) D.Don. ex Sweet; CB: C. bengalensis L.; CC: C. clavata C.B.Clarke; CD: C. diffusa Burm f; CF: C. fragrans (Lindl.) Woodson; CR: C. repens (Jacq.) L; ML: M. loriformis (Hassk.) Rao \& Kamm.; TF: T. fluminensis Vell.; TP: T. pallida (Rose) D.R.Hunt.; TS: T. spathacea Swartz. ; GA: gallic acid; PCA: protocatechuic acid; p-OH; phydroxybenzoic acid; ChA: chlorogenic acid; VA: vanillic acid; CA: caffeic acid; SyA : syringic acid ; $p$-CA: p-coumaric acid; FA: ferulic acid; SA: sinapic acid. ND. = not detected.

Table 4. Contents of flavonoid compounds in selected species from Commelinaceae

\begin{tabular}{|c|c|c|c|c|c|c|}
\hline \multirow{2}{*}{ Sample name } & \multicolumn{5}{|c|}{ Flavonoid compounds ( $\mu \mathrm{g} / 100 \mathrm{~g}$ g DW samples) } & \multirow{2}{*}{ Total } \\
\hline & Rutin & Myricetin & Quercetin & Apigenin & Kaempferol & \\
\hline C. axillaris (L.) D.Don. ex Sweet & $990.25 \pm 5.68 \mathrm{~d}$ & $9933.43 \pm 44.88 \mathrm{a}$ & $19.95 \pm 1.18 \mathrm{~g}$ & $1293.59 \pm 37.78 \mathrm{f}$ & $277.35 \pm 4.21 \mathrm{f}$ & $12514.57 \pm 18.75 \mathrm{~b}$ \\
\hline C. bengalensis $\mathrm{L}$. & $399.09 \pm 10.04 \mathrm{e}$ & $4977.82 \pm 91.08 \mathrm{e}$ & $317.68 \pm 14.91 \mathrm{~b}$ & $980.79 \pm 14.38 \mathrm{~g}$ & $725.19 \pm 25.57 \mathrm{a}$ & $7400.57 \pm 31.20 \mathrm{f}$ \\
\hline C. diffusa Burm.f. & $2039.06 \pm 26.47 \mathrm{a}$ & $1387.54 \pm 23.61 \mathrm{~h}$ & $30.87 \pm 1.48 \mathrm{f}$ & $6280.97 \pm 7.99 \mathrm{a}$ & $290.59 \pm 9.07 \mathrm{e}$ & $10029.03 \pm 28.11 \mathrm{~d}$ \\
\hline C. clavata C.B.Clarke & $11460.44 \pm 89.07 \mathrm{c}$ & $6217.15 \pm 40.59 \mathrm{c}$ & $19.32 \pm 0.08 \mathrm{~g}$ & $1294.30 \pm 82.24 \mathrm{f}$ & $343.11 \pm 7.53 \mathrm{~d}$ & $19334.32 \pm 47.91 \mathrm{a}$ \\
\hline C. fragrans (Lindl.) Woodson & $582.97 \pm 8.24 \mathrm{f}$ & $6533.98 \pm 39.40 \mathrm{~b}$ & $362.49 \pm 5.01 \mathrm{a}$ & $2470.55 \pm 34.53 \mathrm{~b}$ & $149.67 \pm 12.92 \mathrm{i}$ & $10099.66 \pm 40.02 \mathrm{c}$ \\
\hline C. repens (Jacq.) L. & $1933.11 \pm 30.35 \mathrm{~b}$ & $3889.49 \pm 54.09 \mathrm{fg}$ & $158.56 \pm 4.30 \mathrm{~d}$ & $1454.06 \pm 7.96 \mathrm{e}$ & $212.90 \pm 14.94 \mathrm{~h}$ & $7648.12 \pm 35.93 \mathrm{e}$ \\
\hline M. loriformis (Hassk.) Rao \& Kamm. & $95.49 \pm 1.54 \mathrm{i}$ & $313.98 \pm 9.05 \mathrm{i}$ & $165.81 \pm 3.56 \mathrm{c}$ & $291.57 \pm 4.20 \mathrm{i}$ & $425.72 \pm 20.05 b$ & $1292.57 \pm 7.68 \mathrm{j}$ \\
\hline T. fluminensis Vell & $54.86 \pm 2.41 \mathrm{j}$ & $3930.59 \pm 28.95 \mathrm{f}$ & $29.44 \pm 2.27 \mathrm{f}$ & $1673.70 \pm 35.25 \mathrm{~d}$ & $724.88 \pm 6.61 \mathrm{a}$ & $6413.47 \pm 15.10 \mathrm{~h}$ \\
\hline T.pallida(Rose) D.R.Hunt. & $131.13 \pm 3.20 \mathrm{~h}$ & $3873.22 \pm 50.01 \mathrm{fg}$ & $17.12 \pm 0.06 \mathrm{~h}$ & $1928.89 \pm 12.77 \mathrm{c}$ & $364.81 \pm 34.50 \mathrm{c}$ & $6315.17 \pm 43.12 \mathrm{i}$ \\
\hline T. spathacea Swartz. & $270.60 \pm 3.57 \mathrm{~g}$ & $5929.79 \pm 36.58 \mathrm{~d}$ & $33.92 \pm 1.86 \mathrm{e}$ & $606.02 \pm 21.76 \mathrm{~h}$ & $259.05 \pm 5.80 \mathrm{~g}$ & $7099.38 \pm 13.92 \mathrm{~g}$ \\
\hline
\end{tabular}

Values are expressed as mean $\pm S D$ of triplicate measurements $(n=3)$. Means with different letters are significantly different at $\mathrm{p}<0.05$ within the same column. 
The antioxidant activities were expressed as DPPH radical scavenging activity shown by trolox equivalent concentration (TE) and FRAP value (Table 5).

DPPH is a stable free radical that has a purple colour. It has been used to evaluate the free radical scavenging activity. The deep purple colour of DPPH will become colourless or yellow after adding antioxidant material (Sánchez-Moreno et al., 1998). The colour changes occur due to transferring an electron or hydrogen atom to the DPPH by antioxidant materials. The absorbance of the remaining DPPH was determined at 517 $\mathrm{nm}$ using a microplate reader. In this study, the DPPH radical-scavenging activities were measured as mgTrolox equivalent of all samples (Table 5). The DPPH radical scavenging activity exhibited a wide range from 9.6 in T. fluminensis Vell. to $38.0 \mathrm{mgTE} / \mathrm{g}$ DW in $C$. fragrans. These DPPH radical scavenging activity differences appear to have no statistical significance in C. fragrans (Lindl.) Woodson. and C. clavata C.B.Clarke, as they displayed the highest scavenging effect with 38.0 and $37.2 \mathrm{mg}$ TE/g DW, respectively, followed by $C$. bengalensis L., C. axillaris (L.) D.Don. ex Sweet and T. spathacea Swartz. with the values of 21.2, 19.6 and 17.9 $\mathrm{mg}$ TE/g DW $(p<0.05)$.

FRAP, Ferric Reducing Antioxidant Power, is a direct method for determination of the antioxidant capacities (Benzie and Strain, 1996). Antioxidant is a reductant for the redox-linked colorimetric reaction. This method is based on the reduction of a ferric tripyridyltriazine ( $\mathrm{Fe}^{3+}-\mathrm{TPTZ}$ ) complex to $\mathrm{Fe}^{2+}$-TPTZ (blue-coloured) at a low $\mathrm{pH}$. The change in absorption of $\mathrm{Fe}^{2+}-\mathrm{TPTZ}$ was monitored at $593 \mathrm{~nm}$ using a microplate reader. The FRAP values of the Commelinaceae samples are presented in Table 5. It was found that C. diffusa Burm.f. had excellent reducing power (123.0 $\mathrm{mg} \mathrm{FeSO}_{4} / \mathrm{g} \mathrm{DW}$ ), after that $C$. fragrans (Lindl.) Woodson (104.7 $\left.\mathrm{mg} \mathrm{FeSO}_{4} / \mathrm{g} \mathrm{DW),} \mathrm{C.} \mathrm{axillaris} \mathrm{(L.)} \mathrm{D.Don.} \mathrm{ex} \mathrm{Sweet} \mathrm{(} 92.3 \mathrm{mg} \mathrm{FeSO}_{4} / \mathrm{g} \mathrm{DW}\right)$, C. bengalensis L. (64.1 $\left.\mathrm{mgFeSO}_{4} / \mathrm{g} \mathrm{DW}\right)$, T. spathacea Swartz (63.3 $\left.\mathrm{mg} \mathrm{FeSO}_{4} / \mathrm{gDW}\right)$, T. pallida (Rose) D.R.Hunt. ( $48.5 \mathrm{mg}$ $\mathrm{FeSO}_{4} / \mathrm{gDW}$ ), T. fluminensis Vell. (42.6 mg FeSO$/ \mathrm{gDW}$ ), C. diffusa Burm.f (39.2 $\left.\mathrm{mg} \mathrm{FeSO}_{4} / \mathrm{gDW}\right), C$. repens (Jacq.) L. (28.2 mg FeSO $4 / \mathrm{gDW}$ ) and then M. loriformis (Hassk.) Rao \& Kamm. (17.6 mg $\mathrm{FeSO}_{4} / \mathrm{gDW}$ ). It has been observed that there was a wide variation in the antioxidant activities among Commelinaceae samples used in this study. Deviation in antioxidant activity values may be predictable due to variations in environmental and growth conditions.

Table 5. Antioxidant activities of Commelinaceae

\begin{tabular}{|l|c|c|}
\hline \multicolumn{1}{|c|}{ Sample name } & DPPH $(\mathrm{mg} \mathrm{TE} / \mathrm{g} \mathrm{DW})$ & FRAP $\left(\mathrm{mg} \mathrm{FeSO}_{4} / \mathrm{g}\right.$ DW $)$ \\
\hline C. axillaris (L.) D.Don. ex Sweet & $19.62 \pm 0.38 \mathrm{c}$ & $92.33 \pm 1.43 \mathrm{c}$ \\
\hline C. bengalensis L & $21.23 \pm 1.01 \mathrm{~b}$ & $64.14 \pm 1.22 \mathrm{~d}$ \\
\hline C. diffusa Burm.f. & $37.21 \pm 2.80 \mathrm{a}$ & $123.06 \pm 4.18 \mathrm{a}$ \\
\hline C. clavata C.B.Clarke & $14.37 \pm 0.95 \mathrm{e}$ & $39.25 \pm 0.77 \mathrm{~g}$ \\
\hline C. fragrans (Lindl.) Woodson & $38.01 \pm 2.75 \mathrm{a}$ & $104.77 \pm 1.45 \mathrm{~b}$ \\
\hline C. repens (Jacq.) L. & $9.76 \pm 0.17 \mathrm{~g}$ & $28.27 \pm 1.06 \mathrm{~h}$ \\
\hline M. loriformis (Hask.) Rao \& Kamm. & $10.60 \pm 0.45 \mathrm{f}$ & $17.60 \pm 0.50 \mathrm{i}$ \\
\hline T. fluminensis Vell & $9.64 \pm 0.10 \mathrm{~g}$ & $42.63 \pm 1.93 \mathrm{f}$ \\
\hline T. pallida (Rose) D.R.Hunt. & $9.70 \pm 0.46 \mathrm{~g}$ & $48.58 \pm 1.27 \mathrm{e}$ \\
\hline T. spathacea Swartz. & $17.95 \pm 0.98 \mathrm{~d}$ & $63.31 \pm 2.15 \mathrm{~d}$ \\
\hline
\end{tabular}

Values are expressed as mean \pm SD of triplicate measurements $(n=3)$. Means with different letters $(a, b, c, d)$ are significantly different at $p<0.05$ within the same column. FRAP: Ferric reducing antioxidant activities; DPPH radical scavenging activities

\section{Conclusions}

This research has identified and compared key bioactive compounds and the biological activities of 10 selected species from Commelinaceae discovered in the north-eastern region of Thailand. The amino acid, bioactive compounds and antioxidants of some species of Commelinaceae have been revealed for the first time. 
These genotypes were rich in phenolic compounds and flavonoids, with their concentrations varying widely. C. clavata C.B.Clarke and C. fragrans (Lindl.) Woodson were the richest source of phenolic acid and flavonoids, followed by $C$. diffusa Burmf. Our findings suggest that $C$. clavata C.B.Clarke was the most promising source of bioactive compounds. Regarding the biological activities, C. clavata C.B.Clarke appears to display the highest antioxidant activity, followed by $C$. fragrans (Lindl.) Woodson and C. bengalensis L. Gallic acid, $p$-hydroxybenzoic acid, p-coumaric acid, sinapic acid and all flavonoids were detected in all samples. The findings suggest that bioactive compounds (phenolic compounds and vitamin c) responsible for antioxidant activity. The results obtained from our study have provided useful information for the potential use of Commelinaceae as functional foods or cosmetics products. The results from our present study have demonstrated that the bioactive compounds and biological activities varied greatly among the varieties, however the bioactive compounds and biological activities were variable and may also be related to different environmental conditions using the discriminant and cluster analysis method. Therefore, further studies should include the influence of the environment and growth conditions as well as processing methods on these bioactive compounds and biological activities.

\section{Authors' Contributions}

TC and SS performed the conception and design of study. TC: analysis and/or interpretation of data designed. TC and SS wrote the manuscript and reviewed the final manuscript for journal submission. Both authors read and approved the final manuscript.

\section{Acknowledgements}

This work was financially supported by the Thailand Science Research and Innovation (TSRI) 2021 fund. The authors would like to thank the Laboratory Equipment Center of Mahasarakham University for cooperation and scientific aid. We also gratefully thank Dr. Jolyon Dodgson who is an agriculturist, crop scientist and plant pathologist from the UK for language editing and suggestions to improve the manuscript.

\section{Conflict of Interests}

The authors declare that there are no conflicts of interest related to this article.

\section{References}

Al-Duais M, Müller L, Böhm V, Jetschke G (2009). Antioxidant capacity and total phenolics of Cyphostemma digitatum before and after processing: use of different assays. European Food research and Technology 228:813-821. https://doi.org/10.1007/s00217-008-0994-8

Alonso-Castro AJ, Villarreal ML, Salazar-Olivo LA, Gomez-Sanchez M, Dominguez F, Garcia-Carranca A (2011). Mexican medicinal plants used for cancer treatment: pharmacological, phytochemical and ethnobotanical studies. Journal of Ethnopharmacology 133:945-972. https://doi.org/10.1016/j.jep.2010.11.055

Benzie IF, Strain JJ (1996). The ferric reducing ability of plasma (FRAP) as a measure of "antioxidant power": the FRAP assay. Analytical Biochemistry 239:70-76. https://doi.org/10.1006/abio.1996.0292

Butsat S, Weerapreeyakul N, Siriamornpun S (2009). Changes in phenolic acids and antioxidant activity in Thai rice husk at five growth stages during grain development. Journal of Agricultural and Food Chemistry 57:4566-4571. https://doi.org/10.1021/jf9000549 
Cheeptham N, Towers GHN (2002). Light-mediated activities of some Thai medicinal plant teas. Fitoterapia 73(78):651-662. https://doi.org/10.1016/S0367-326X(02)00224-1

Chumroenphat T, Somboonwatthanakul I, Saensouk S, Siriamornpun S (2019). The diversity of biologically active compounds in the rhizomes of recently discovered Zingiberaceae plants native to North Eastern Thailand. Pharmacognosy Journal 11. http://dx.doi.org/10.5530/pj.2019.11.160

Chumroenphat T, Somboonwatthanakul I, Saensouk S, Siriamornpun S (2021). Changes in curcuminoids and chemical components of turmeric (Curcuma longa L.) under freeze-drying and low-temperature drying methods. Food Chemistry 339. https://doi.org/10.1016/j.foodchem.2020.128121

Edeoga HO, Ogbebor NO (1999). Distribution of calcium oxalate crystals in some Nigerian species of Aneilema R. Br. (Commelinaceae). Plant Biosystem 133:193-198. https://doi.org/10.1080/11263509909381548

Ghasemzadeh A, Jaafar H Z, Rahmat A (2010). Antioxidant activities, total phenolics and flavonoids content in two varieties of Malaysia young ginger (Zingiber officinale Roscoe). Molecules 15:4324-4333. https://doi.org/10.3390/molecules15064324

González-Avila M, Arriaga-Alba M, De la Garza M, del Carmen Hernández Pretelín M, Domınguez-Ortız MA, FattelFazenda S, Villa-Trevino S (2003). Antigenotoxic, antimutagenic and ROS scavenging activities of a Rhoeo discolor ethanolic crude extract. Toxicology in Vitro 17:77-83. https://doi.org/10.1016/S08872333(02)00120-0

Huang M, Zhang H, Zhao C, Chen G, Zou Y (2019). Amino acid content in rice grains is affected by high temperature during the early grain-filling period. Scientific Reports 9:1-7. https://doi.org/10.1038/s41598-019-38883-2

Kaisoon O, Konczak I, Siriamornpun S (2012). Potential health enhancing properties of edible flowers from Thailand. Food Research International 46:563-571. https://doi.org/10.1016/j.foodres.2011.06.016

Kamble S (2019). Nutraceutical investigations of Commelina diffusa Burm. f. leaves-a popular wild vegetable. Plantae Scientia 2:34-39. https://doi.org/10.32439/ps.v2i3.34-39

Khalid II, Elhardallou SB, Gobouri AA (2016). Amino acid composition and physicochemical properties of bitter lupine (Lupinustermis) seed flour. Oriental Journal of Chemistry 32(6):3175. http://dx.doi.org/10.13005/ojc/320640

Kokilavani P, Suriyakalaa U, Elumalai P, Abirami B, Ramachandran, R, Sankarganesh A, Achiraman S (2014). Antioxidant mediated ameliorative steroidogenesis by Commelina benghalensis L. and Cissus quadrangularis L. against quinalphos induced male reproductive toxicity. Pesticide Biochemistry and Physiology 109:18-33. https://doi.org/10.1016/j.pestbp.2014.01.002

Kubola J, Siriamornpun S, Meeso N (2011). Phytochemicals, vitamin C and sugar content of Thai wild fruits. Food Chemistry 126:972-981. https://doi.org/10.1016/j.foodchem.2010.11.104

Kunnaja P, Wongpalee SP, Panthong A (2014). Evaluation of anti-inflammatory, analgesic, and antipyretic activities of the ethanol extract from Murdannia loriformis (Hassk.) Rolla Rao et Kammathy. BioImpacts BI4:183. https://dx.doi.org/10.15171\%2Fbi.2014.018

Li D, Li B, Ma Y, Sun X, Lin Y, Meng X (2017). Polyphenols, anthocyanins, and flavonoids contents and the antioxidant capacity of various cultivars of highbush and half-high blueberries. Journal of Food Composition and Analysis 62:84-93. https://doi.org/10.1016/j.jfca.2017.03.006

Mensah AY, Houghton PJ, Dickson RA, Fleischer TC, Heinrich M, Bremner P (2006). In vitro evaluation of effects of two Ghanaian plants relevant to wound healing. Phytotherapy Research 20:941-944. https://doi.org/10.1002/ptr.1978

Myriam AA, Luis BJ, Jannete R P N, Jaime SN, Roberto RS, Marisela GA (2011). Antimutagenicity mechanisms of the Rhoeo discolor ethanolic extract. Experimental and Toxicologic Pathology 63:243-248. https://doi.org/10.1016/j.etp.2010.01.001

Ratseewo J, Meeso N, Siriamornpun S (2020). Changes in amino acids and bioactive compounds of pigmented rice as affected by far-infrared radiation and hot air drying. Food Chemistry 306. https://doi.org/10.1016/j.foodchem.2019.125644

Regis AS, Gabriel JJ (2017). Antifungal activity of Cyanotis axillaris (1.) d. DON EX sweet against opportunistic fungal strains. International Journal of Pharmacy and Pharmaceutical Sciences 9(7):140-143. https://doi.org/10.22159/ijpps.2017v9i7.18868

Ribeiro B, Andrade PB, Silva BM, Baptista P, Seabra RM, Valentao P (2008). Comparative study on free amino acid composition of wild edible mushroom species. Journal of Agricultural and Food Chemistry 56:10973-10979. https://doi.org/10.1021/jf802076p 
Rivero-Pérez MD, MUNiz PILAR., González-Sanjosé ML (2007). Antioxidant profile of red wines evaluated by total antioxidant capacity, scavenger activity, and biomarkers of oxidative stress methodologies. Journal of Agricultural and Food Chemistry 55:5476-5483. https://doi.org/10.1021/jf070306q

Sánchez-Moreno C, Larrauri JA, Saura-Calixto F (1998). A procedure to measure the antiradical efficiency of polyphenols. Journal of the Science of Food and Agriculture 76:270-276. https://doi.org/10.1002/(SICI)10970010(199802)76:2\%3C270::AID-JSFA945\%3E3.0.CO;2-9

Siriamornpun S, Kaewseejan N (2017). Quality, bioactive compounds and antioxidant capacity of selected climacteric fruits with relation to their maturity. Scientia Horticulturae 221:33-42. https://doi.org/10.1016/j.scienta.2017.04.020

Tan JBL, Yap W J, Tan SY, Lim YY, Lee SM (2014). Antioxidant content, antioxidant activity, and antibacterial activity of five plants from the Commelinaceae family. Antioxidants 3:758-769. https://doi.org/10.3390/antiox3040758

Tan, JBL, Kwan YM (2020). The biological activities of the spiderworts (Tradescantia). Food Chemistry 317. https://doi.org/10.1016/j.foodchem.2020.126411

Wilson AK (1981). Commelinaceae-A review of the distribution, biology and control of the important weeds belonging to this family. International Journal of Pest Management 27:405-418. https://doi.org/10.1080/09670878109413812

Zhishen J, Mengcheng T, Jianming W (1999). The determination of flavonoid contents in mulberry and their scavenging effects on superoxide radicals. Food Chemistry 64:555-559. https://doi.org/10.1016/S0308-8146(98)00102-2
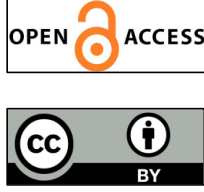

The journal offers free, immediate, and unrestricted access to peer-reviewed research and scholarly work. Users are allowed to read, download, copy, distribute, print, search, or link to the full texts of the articles, or use them for any other lawful purpose, without asking prior permission from the publisher or the author.

License - Articles published in Notulae Botanicae Horti Agrobotanici Cluj-Napoca are Open-Access, distributed under the terms and conditions of the Creative Commons Attribution (CC BY 4.0) License. (c) Articles by the authors; UASVM, Cluj-Napoca, Romania. The journal allows the author(s) to hold the copyright/to retain publishing rights without restriction. 